\title{
Age-dependent prevalence of antibodies cross-reactive to the influenza $A(H 3 N 2)$ variant virus in sera collected in Norway in 2011
}

K Waalen (kristian.waalen@fhi.no) ${ }^{1}$, A Kilander ${ }^{1}$, S G Dudman ${ }^{1}$, R Ramos-Ocao $^{1}, 0$ Hungnes ${ }^{1}$

1. Department of Virology, Norwegian Institute of Public Health, Oslo, Norway

Citation style for this article:

Waalen K, Kilander A, Dudman SG, Ramos-Ocao R, Hungnes O. Age-dependent prevalence of antibodies cross-reactive to the influenza A(H3N2) variant virus in sera collected in Norway in 2011. Euro Surveill. 2012;17(19):pii=20170. Available online: http://www.eurosurveillance.org/ViewArticle.aspx?Articleld=20170

Article submitted on 09 May 2012/ published on 10 May 2012

Antibody cross-reactivity to the influenza $\mathrm{A}\left(\mathrm{H}_{3} \mathrm{~N}_{2}\right)$ variant virus recently reported in the United States, was investigated in Norwegian sera. Seroprevalence was $40 \%$ overall, and $71 \%$ in people born between 1977 and 1993. The most susceptible age groups were children and people aged around 50 years. The high immunity in young adults is likely to be due to strong priming infection with similar viruses in the 1990 . More research is needed to explain the poor immunity in 45-54 year-olds.

\section{Introduction}

From August 2011 to April 2012, 13 cases of human infection were identified in the United States (US) with a variant of influenza $\mathrm{A}\left(\mathrm{H}_{3} \mathrm{~N}_{2}\right)$ virus that had been circulating in pigs in North America. The variant has been designated as $\mathrm{A}\left(\mathrm{H}_{3} \mathrm{~N}_{2}\right) \mathrm{v}$ by the World Health Organization (WHO) [1]. Almost all cases have been in children, some of them with no recognised exposure to pigs, and limited human-to-human transmission appears to have occurred [2-5]. These viruses have not been shown to circulate in European swine, and until now no human influenza $\mathrm{A}\left(\mathrm{H}_{3} \mathrm{~N}_{2}\right) \mathrm{v}$ cases have been reported in Europe.

The haemagglutinin of these $\mathrm{H}_{3} \mathrm{~N}_{2} \mathrm{~V}$ viruses is descended from $\mathrm{H}_{3} \mathrm{~N}_{2}$ viruses that were circulating worldwide in humans in the mid-1990s [6], with A/ Wuhan/359/1995( $\left.\mathrm{H}_{3} \mathrm{~N}_{2}\right)$-like viruses the most similar vaccine strain [7].

In order to assess the risk and possible impact of further spread of influenza $\mathrm{A}\left(\mathrm{H}_{3} \mathrm{~N}_{2}\right) \mathrm{v}$ viruses in the human population, we need to clarify whether prior exposure to earlier antigenic variants of human $\mathrm{H}_{3} \mathrm{~N}_{2}$ viruses, either through infection or through vaccination, may have resulted in persisting immunity that could protect segments of the population today against the current $\mathrm{H}_{3} \mathrm{~N}_{2} \mathrm{~V}$ virus.

Although the genetic similarities to previously circulating viruses suggest that pre-existing immunity may exist, it is important to corroborate this with seroepidemiological evidence. This study presents a first analysis of antibodies reactive to the $\mathrm{H}_{3} \mathrm{~N}_{2} \mathrm{~V}$ virus in a panel of human sera collected in Norway in August 2011.

\section{Methods}

In August each year, The Norwegian Annual Influenza Seroepidemiology Programme collects a panel of anonymised convenience sera representative geographically and for all age groups (about 2,200 sera per year) [8]. In the present study, we used a sub-panel $(n=253)$ of the serum collection from August 2011 containing sera from hospital laboratories in three counties representing different geographic areas of Norway (Bodø, Stavanger and Oslo). The collection and testing of these serum samples for influenza seroepidemiology has been approved by the local research ethics board.

Serum antibody titres were determined using the haemagglutination inhibition ( $\mathrm{HI}$ ) assay, testing sera in serial two-fold dilutions starting at dilution 1:10, with turkey red blood cells (RBC) as indicator cells [8] and taking as the $\mathrm{HI}$ titre the serum dilution factor that produced complete inhibition in the assay. An HI titre of 40 or higher against a particular influenza virus is widely considered to be associated with reduced risk for infection [9]. Our experience is that turkey RBC give more stable results when compared to RBC from other species. We have not used other RBCs in this study. For calculations of geometric mean titres, sera with titres <10 were assigned an $\mathrm{HI}$ titre of 5 . Differences by age group in the proportion of sera with protective $\mathrm{HI}$ antibody titres were analysed for statistical significance using the chi-square and Fisher's exact test. Differences in titres between age groups were analysed using the non-parametric Kruskal-Wallis test. All statistical analyses were undertaken in PASW Statistics 17 (version 17.0.2; SPSS Inc, Chicago).

The influenza $A /$ Indiana/o8/2011 $\left(\mathrm{H}_{3} \mathrm{~N}_{2}\right) v$ virus was provided by the WHO Collaborating Centre for Reference 
and Research on Influenza at the National Institute for Medical Research in London (WHO CC/UK) through the WHO Global Influenza Surveillance and Response System (GISRS) under terms applying to the sharing of Pandemic Influenza Preparedness Biological Materials [10]. The virus was grown in Madin-Darby canine kidney (MDCK) cells and used non-inactivated as antigen in the $\mathrm{HI}$ assay. All work with the $\mathrm{A}\left(\mathrm{H}_{3} \mathrm{~N}_{2}\right)$ v virus was performed in a biosafety level 2 facility employing biosafety level 3 procedures and precautions. A/ Wuhan/359/1995 $\left(\mathrm{H}_{3} \mathrm{~N}_{2}\right)$ has not been included in this study, but we plan a more comprehensive study using this virus.

\section{Results}

A considerable overall proportion, $40 \%$, of the analysed sera contained antibody to the $\mathrm{H}_{3} \mathrm{~N}_{2} \mathrm{~V}$ virus with $\mathrm{HI}$ titres correlating with protection ( $\mathrm{HI}$ titre $\geq 40$ ) (Table 1).

A distinctive age-related pattern was observed. Very high proportions of approximately $71 \%$ were seen in people born between the late 1970 s and the early 1990 s (Figure, panel A). High proportions of 40 to $50 \%$ presumably seroprotective antibodies were also seen in the age group born between 1967 and 1976 as well as in persons born in the mid-1950s or earlier. In particular, in children born in 1999 or later, no protective $\mathrm{HI}$ titres to the $\mathrm{H}_{3} \mathrm{~N}_{2} \mathrm{~V}$ virus were seen. Children born in the latter part of the 1990 s showed a seropositivity rate of $16 \%$.

Remarkably, the prevalence of seroprotective antibodies to the $\mathrm{H}_{3} \mathrm{~N}_{2} \mathrm{~V}$ virus was low, with $14 \%$, in people born in the last part of the 1950 s and the first part of the 1960 s. This low seroprevalence was significantly different from other adult age groups (Table 2). The seroprevalence results were in general also reflected by the pattern of geometric mean titres in the respective age groups (Figure, panel B and Table 1). Statistical significance was reached for many of the differences between age groups in seroprevalence and antibody levels (Table 2).

\section{Discussion}

We have investigated the occurrence of antibodies reactive to the influenza $A\left(\mathrm{H}_{3} \mathrm{~N}_{2}\right) v$ virus in a serum panel representing all age groups from o to 97 years. The finding of a considerable antibody prevalence in persons who were young in the 1990 i.e. those between 18 and 34 years old, is in good agreement with the fact that the haemagglutinin gene of the $\mathrm{H}_{3} \mathrm{~N}_{2} \mathrm{~V}$ viruses is descended from a human $\mathrm{H}_{3} \mathrm{~N}_{2}$ antigenic variant that was circulating in the mid-1990s [7], represented by the vaccine virus $\mathrm{A} /$ Wuhan/359/1995.

That the young adults had persisting antibody-mediated immunity to virus variants that they presumably were exposed to during their childhood years is not unexpected and is in good agreement with previous observations that have led to or supported the 'original antigenic sin' concept [11].

Our findings are also in agreement with two other recent studies. In sera from a Canadian vaccine study in 2010 it has been demonstrated that antibodies to $\mathrm{H}_{3} \mathrm{~N}_{2} \mathrm{~V}$ increase with age in children and decreases with age in adults [12]. The subjects of that study, however, did not include children between 10 and 19 years of age or the elderly, and thus could not provide a full age profile of the seroprevalence. Similarly, in a recent study of sera from a US vaccine study in 2010-11 as well as sera from a 2007-08 health survey, children under the age of 10 years had little or no cross-reactive

\section{TABLE 1}

Cross-reactive antibodies to influenza A/Indiana/08/11(H3N2)v virus, by age group, Norway, sera collected in August 2011 $(n=253)$

\begin{tabular}{|c|c|c|c|c|c|c|c|c|}
\hline \multirow{2}{*}{$\begin{array}{l}\text { Age group } \\
\text { (years) }\end{array}$} & \multirow{2}{*}{$\begin{array}{l}\text { Age span in } \\
\text { group }\end{array}$} & \multirow{2}{*}{ Birth years } & \multirow{2}{*}{$\mathrm{n}$} & \multicolumn{3}{|c|}{ Sera with $\mathrm{HI}$ titre $\geq 40$} & \multicolumn{2}{|c|}{ Geometric mean titre } \\
\hline & & & & $\mathrm{n}$ & $\%$ & $95 \% \mathrm{Cl}$ & Titre & $95 \% \mathrm{Cl}$ \\
\hline $0-12$ & 12 & 2011-1999 & 47 & 0 & 0 & - & 5.6 & $(5.1-6.3)$ \\
\hline $13-17$ & 5 & $1998-1994$ & 19 & 3 & 16 & $(4-37)$ & 11.2 & $(7.3-17.0)$ \\
\hline $18-24$ & 7 & $1993-1987$ & 28 & 20 & 71 & $(53-86)$ & 37.1 & $(26.5-52.1)$ \\
\hline $25-34$ & 10 & $1986-1977$ & 45 & 32 & 71 & $(57-83)$ & 40.6 & $(31.2-52.9)$ \\
\hline $35-44$ & 10 & $1976-1967$ & 27 & 13 & 48 & $(30-67)$ & 26.5 & $(20.3-34.6)$ \\
\hline $45-54$ & 10 & $1966-1957$ & 22 & 3 & 14 & $(4-33)$ & 11.0 & $(7.6-15 \cdot 9)$ \\
\hline $55-64$ & 10 & $1956-1947$ & 22 & 9 & 41 & $(22-62)$ & 18.2 & $(11.9-27.9)$ \\
\hline $65-74$ & 10 & $1946-1937$ & 26 & 13 & 50 & $(31-69)$ & 24.8 & $(17.1-35.8)$ \\
\hline $75-97$ & 23 & $1936-1914$ & 17 & 9 & 53 & $(30-75)$ & 22.6 & $(12.5-40.9)$ \\
\hline All ages & - & $1914-2011$ & 253 & 102 & 40 & $(34-47)$ & 18.4 & $(16.1-21.0)$ \\
\hline
\end{tabular}




\section{FIGURE}

Cross-reactive antibodies to influenza A/Indiana/08/11(H3N2)v virus, Norway, sera collected in August 2011 (n=253)

(A)

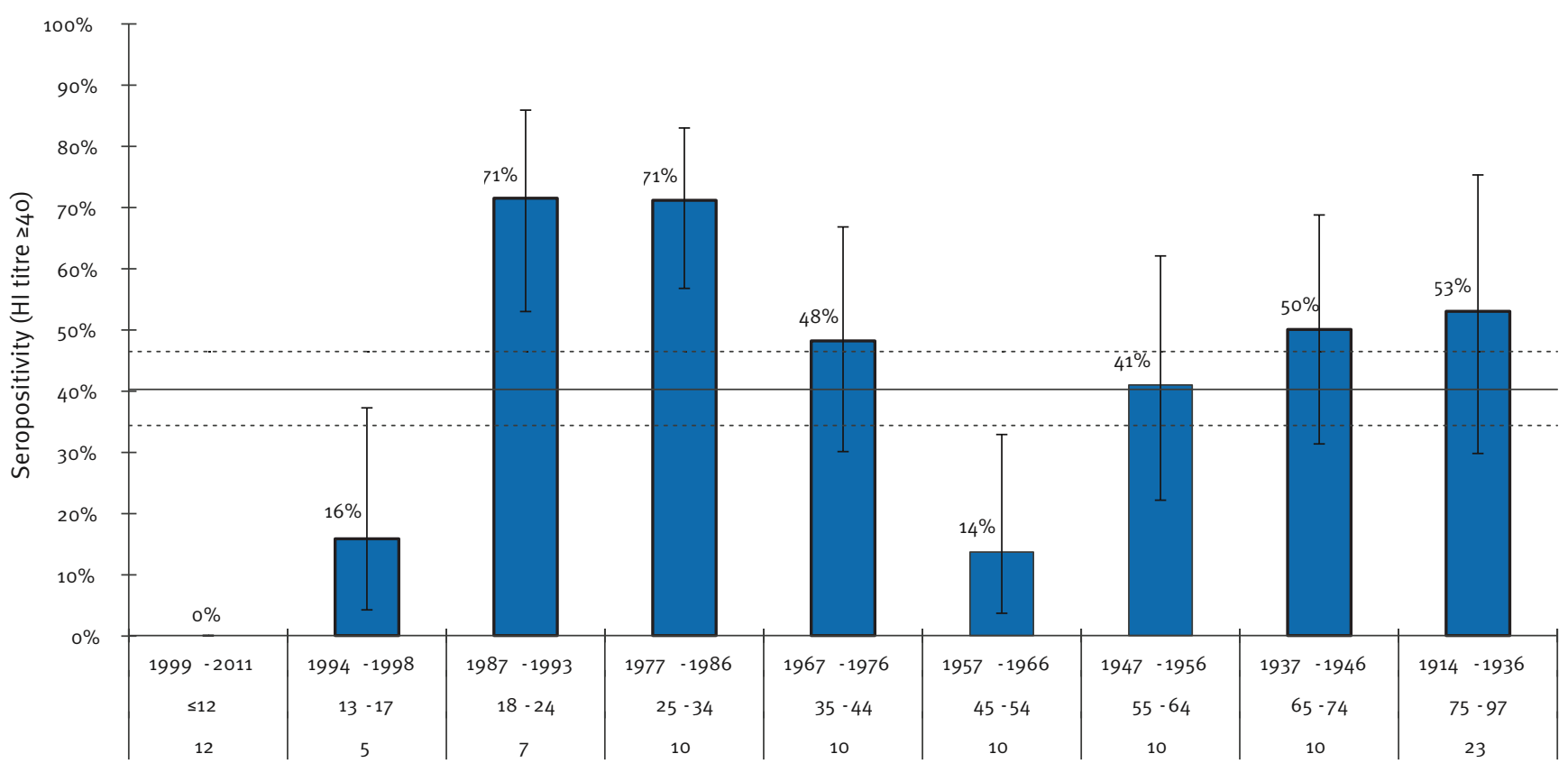

Age groups with years of birth, age in 2011 (years), age span (years) per group

(B)

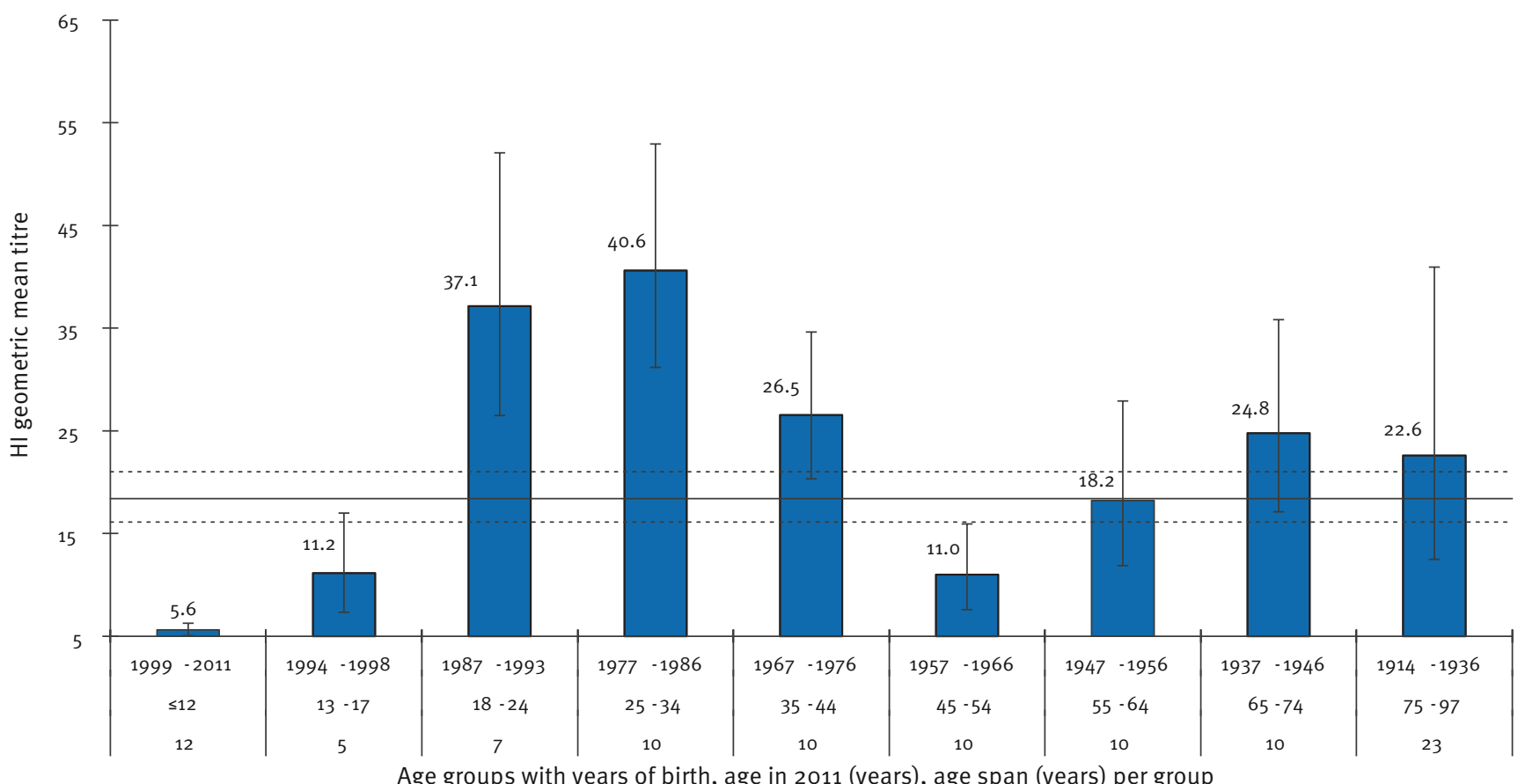

Age groups with years of birth, age in 2011 (years), age span (years) per group

$\mathrm{Cl}$ : confidence interval; $\mathrm{HI}$ : haemagglutinin inhibition.

Panel A: Proportion of sera with $\mathrm{HI}$ titre $\geq 40$ in the various age groups with $95 \% \mathrm{Cl}$ (vertical lines). Percent positivity for 'All ages' is shown (horizontal solid line) with $95 \% \mathrm{Cl}$ (dotted lines).

Panel B: geometric mean $\mathrm{HI}$ titres by age group. Annotations as for panel A. 
antibodies, while some older children and adults had such antibodies [13]. This study did not investigate a continuous age series either, since sera from 50-64 year-old people were missing.

In our study, cross-reactive antibodies to $\mathrm{H}_{3} \mathrm{~N}_{2} \mathrm{~V}$ were virtually absent in children 12 years and younger, which is also in good agreement with the serological data from Canada and the US. This is consistent with the fact that the influenza $A\left(\mathrm{H}_{3} \mathrm{~N}_{2}\right)$ antigenic variant that was predominant in humans in the mid-1990s was, toward the end of the decade, replaced by an antigenically distinct drift variant (represented by A/Sydney/5/1997 and $A /$ Moscow/10/1999) [14]. Individuals born in 1999 or later are thus not expected to have been exposed to the human $\mathrm{H}_{3} \mathrm{~N}_{2}$ viruses that most closely resemble the current $\mathrm{H}_{3} \mathrm{~N}_{2} \mathrm{~V}$ virus. As noted by others, almost all recorded human $\mathrm{H}_{3} \mathrm{~N}_{2} \mathrm{~V}$ infections have occurred in this age group $[5,12,13]$.
However, unexpectedly and not evident in the previous studies from Canada and the US, there was also increasing seroprevalence and increasing mean $\mathrm{HI}$ titre with age in the age group older than 50 years. Conversely, there appeared to be a distinct gap in immunity in persons born in the late 1950 or oarly1960s. We do not have a straightforward explanation for this finding. Persons born before the $1968-70 \mathrm{~A}\left(\mathrm{H}_{3} \mathrm{~N}_{2}\right)$ pandemic would in general be expected to have a similar history of exposure to $\mathrm{H}_{3} \mathrm{~N}_{2}$ antigenic variants, i.e. throughout the entire $\mathrm{H}_{3} \mathrm{~N}_{2}$ era from the 1968 pandemic until today. One could speculate that there may be a certain age span during which individuals are more prone to mount vigorous immune responses to their first infection with a virus, which then dominate over and preclude effective responses against subsequent, antigenically related viruses. Conceivably, individuals who were past that age when they were first exposed to the $\mathrm{H}_{3} \mathrm{~N}_{2}$ viruses during or after the $1968-70$ pandemic

TABLE 2

Statistically significant differences between age groups in cross-reactive antibody titres to influenza A/Indiana/8/11(H3N2)V virus, Norway, sera collected in August $2011(\mathrm{n}=253)$

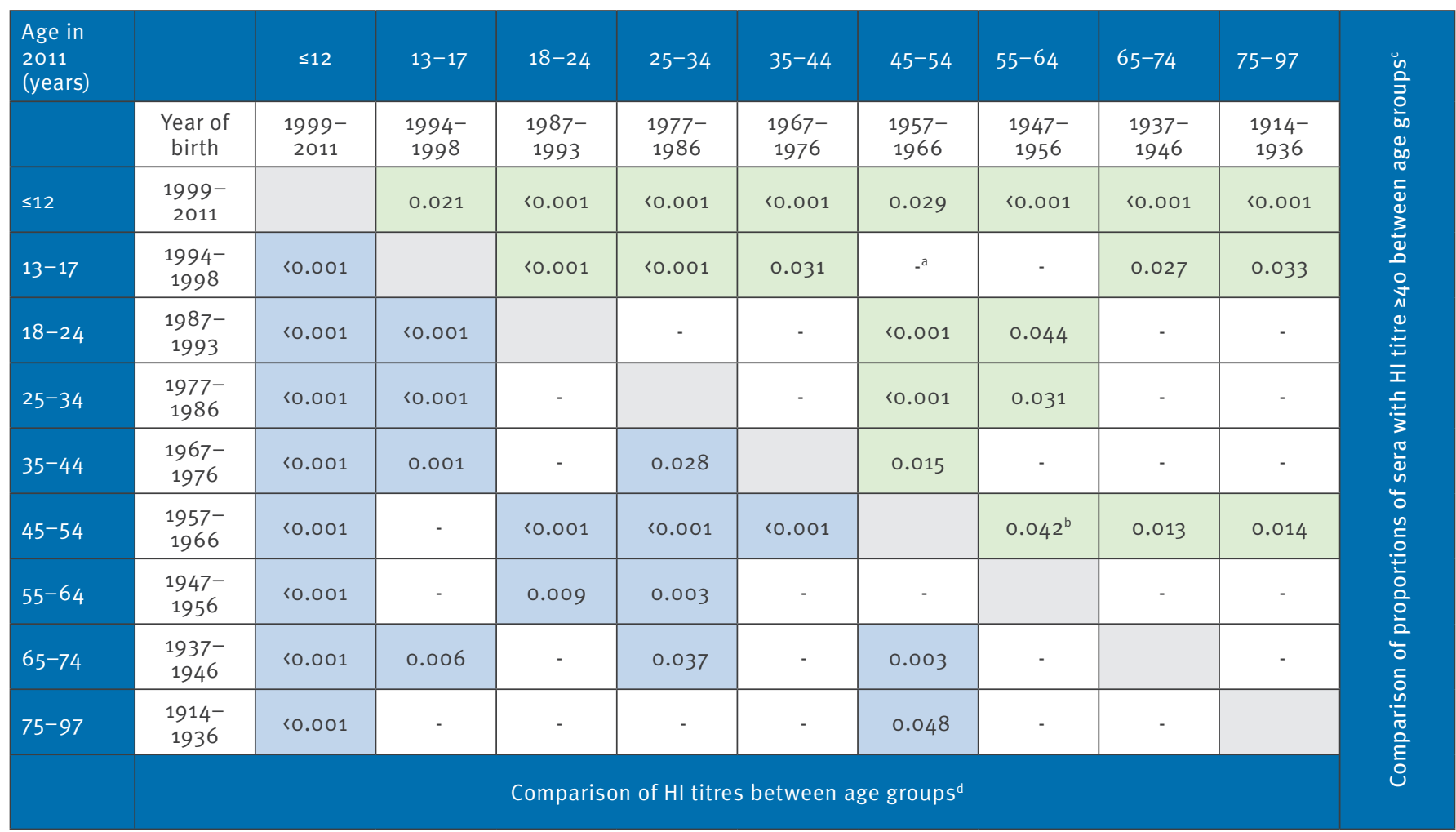

$\mathrm{Cl}$ : confidence interval; $\mathrm{HI}$ : haemagglutinin inhibition.

p values are given for pairs where statistical significance was reached. These positions in the matrix have background colouring. The upperright triangle contains data for differences in seroprevalence, while the lower-left triangle contains data for the differences in antibody levels.

a Not significant (-).

b As determined by chi-square test, $p=0.088$ by Fisher's exact test.

Statistical significance ( $p$ values in light green cells) determined by Fisher's exact test.

Statistical significance ( $p$ values in light blue cells) determined by Kruskal-Wallis test. 
may have mounted a more restrained and adaptable response and thus gradually developed their immunological repertoire in pace with the evolution of the virus, either through adding new epitope specificities or through making antibodies against the most conserved epitopes. Clearly, more research is needed to confirm this observation and to better understand the mechanisms and conditions behind this pattern.

The findings reported here are subject to some limitations. We do not know to which extent the measured cross-reactive antibody in the various age groups correlates with actual protection against infection and illness. A recent study has suggested that the titre needed for protection might be higher for children than for adults [15]. Furthermore, it is widely recognised that the titres determined by the $\mathrm{HI}$ test are prone to considerable variation and the proportion of sera with titres above a certain cut-off thus should not be considered as an absolute measure. However, this is not expected to affect the quite substantial relative differences between age groups that are reported here. Finally, immune responses such as cell mediated immunity and antibody against other antigens than those measured by $\mathrm{HI}$ have not been assessed.

\section{Conclusions and future work}

Our observations provide further knowledge on the possible susceptibility in the population to the current influenza $\mathrm{H}_{3} \mathrm{~N}_{2} \mathrm{~V}$ viruses. The data support and further extend the previous findings by two recent seroepidemiological studies which did not study the complete range of age groups. The considerable prevalence of cross-reactive antibodies suggests that there may be a limit to the epidemic potential of these viruses in their current form. The highest seroprevalence to influenza $\mathrm{A}\left(\mathrm{H}_{3} \mathrm{~N}_{2}\right) \mathrm{v}$ virus is observed in young adults, consistent with persisting immunity caused by exposure in childhood to antigenically and genetically related viruses that were circulating in humans during the mid-1990s. Seroprevalence is very low in children and adolescents that are unlikely to have been exposed to $\mathrm{H}_{3} \mathrm{~N}_{2}$ viruses before they had drifted antigenically away from the mid-1990s variant. However, we also find high seroprevalence in the elderly, while, surprisingly, adults born in the late 1950 s or 1960 s represent a group that appears to have limited immunity against the $\mathrm{H}_{3} \mathrm{~N}_{2} \mathrm{~V}$ virus. Further studies are warranted to better understand the nature of these differences in immunity between age groups that should have been exposed to the same range of $\mathrm{H}_{3} \mathrm{~N}_{2}$ antigenic variants albeit at different stages in life.

\section{Acknowledgements}

We would like to thank laboratories in the following hospitals for their invaluable contribution in providing the residual sera used in the present study: Oslo University Hospital, Stavanger University Hospital, and Nordlandssykehuset/ Bodø. The Indiana State Department of Health Laboratories, Indianapolis, US and the US Centers for Disease Control and Prevention, Atlanta, US, are acknowledged for the provision of the influenza $\mathrm{A}\left(\mathrm{H}_{3} \mathrm{~N}_{2}\right) \mathrm{v}$ virus $\mathrm{A} /$ Indiana/08/2011 to the WHO GISRS network. The WHO Collaborating Centre at the National Institute for Medical Research, London, UK, is gratefully acknowledged for providing this virus as well as the ferret control serum used in the HI test. We further thank the staff of the influenza laboratory, Department of Virology, Norwegian Institute of Public Health; Valentina Johansen, Anne Marie Lund, and Marianne Morken, for excellent technical assistance.

\section{References}

1. World Health Organization (WHO). Standardization of terminology for the variant $\mathrm{A}\left(\mathrm{H}_{3} \mathrm{~N}_{2}\right)$ virus recently infecting humans. Joint announcement of FAO, OIE and WHO. Geneva: WHO; 23 Dec 2011. Available from: http://www.who.int/ influenza/gisrs_laboratory/terminology_ahzn2v/en/index.html

2. Centers for Disease Control and Prevention (CDC). Limited human-to-human transmission of novel influenza $\mathrm{A}\left(\mathrm{H}_{3} \mathrm{~N}_{2}\right)$ virus - lowa, November 2011. MMWR Morb Mortal Wkly Rep. 2011;60(47):1615-7.

3. Centers for Disease Control and Prevention (CDC). Update: Influenza A ( $\left.33 \mathrm{~N}_{2}\right) v$ Transmission and Guidelines - Five States, 2011. MMWR Morb Mortal Wkly Rep. 2012;60(51):1741-4.

4. Lindstrom S, Garten R, Balish A, Shu B, Emery S, Berman L, et al. Human Infections with Novel Reassortant Influenza $\mathrm{A}\left(\mathrm{H}_{3} \mathrm{~N}_{2}\right) v$ Viruses, United States, 2011. Emerg Infect Dis. 2012;18(5):834-7.

5. Centers for Disease Control and Prevention (CDC). First $\mathrm{H}_{3} \mathrm{~N}_{2}$ Variant Virus Infection Reported For 2012. Atlanta: CDC; 12 Apr 2012. Available from: http://www.cdc.gov/flu/spotlights/ h3n2v-variant-utah.htm

6. Webby RJ, Swenson SL, Krauss SL, Gerrish PJ, Goyal SM, Webster RG. Evolution of swine $\mathrm{H}_{3} \mathrm{~N}_{2}$ influenza viruses in the United States. J Virol. 2000;74(18):8243-51.

7. Lina B, Bouscambert M, Enouf V, Rousset D, Valette M, van der Werf S. S-OtrH3 $\mathrm{N}_{2}$ viruses: use of sequence data for description of the molecular characteristics of the viruses and their relatedness to previously circulating $\mathrm{H}_{3} \mathrm{~N}_{2}$ human viruses. Euro Surveill. 2011;16(50):pii=20039. Available from: http://www.eurosurveillance.org/ViewArticle. aspx?Articleld $=20039$

8. Waalen K, Kilander A, Dudman SG, Krogh GH, Aune T, Hungnes O. High prevalence of antibodies to the 2009 pandemic influenza $A\left(\mathrm{H}_{1} \mathrm{~N}_{1}\right)$ virus in the Norwegian population following a major epidemic and a large vaccination campaign in autumn 2009. Euro Surveill. 2010;15(31):pii=19633. Available from: http://www.eurosurveillance.org/ViewArticle. aspx?Articleld $=19633$

9. Potter CW, Oxford JS. Determinants of immunity to influenza infection in man. Br Med Bull. 1979;35(1):69-75.

10. World Health Organization (WHO). Pandemic influenza preparedness Framework for the sharing of influenza viruses and access to vaccines and other benefits. Geneva: WHO; 2011 . Available from: http://www.who.int/influenza/resources/ pip_framework/en/index.html

11. Morens DM, Burke DS, Halstead SB. The wages of original antigenic sin. Emerg Infect Dis. 2010;16(6):1023-4.

12. Skowronski DM, De SG, Janjua NZ, Gardy JL, Gilca V, Dionne $M$, et al. Cross-reactive antibody to swine influenza $\mathrm{A}\left(\mathrm{H}_{3} \mathrm{~N}_{2}\right)$ subtype virus in children and adults before and after immunisation with 2010/11 trivalent inactivated influenza vaccine in Canada, August to November 2010. Euro Surveill 2012;17(4):pii=20066. Available from: http://www. eurosurveillance.org/ViewArticle.aspx?Articleld=20066

13. Centers for Disease Control and Prevention (CDC). Antibodies Cross-Reactive to Influenza A ( $\left.33 \mathrm{~N}_{2}\right)$ Variant Virus and Impact of 2010-11 Seasonal Influenza Vaccine on Cross-Reactive Antibodies - United States. MMWR Morb Mortal Wkly Rep. 2012;61:237-41.

14. Black S, Nicolay U, Vesikari T, Knuf M, Del GG, Della CG, et al. Hemagglutination inhibition antibody titers as a correlate of protection for inactivated influenza vaccines in children. Pediatr Infect Dis J. 2011;30(12):1081-5. 